結腸膀胱瘦を合併した S 状結腸憩室症の一治験例

川崎医科大学附属川崎病院外科

同 泌尿器科

\begin{tabular}{|c|c|c|c|c|c|c|c|c|c|c|}
\hline 野 & 正 & 人 & 野 & 田 & 和 & 人 & 韩 & & 倉 & \\
\hline 田 & 育 & 宏 & 田 & 原 & 昌 & 人 & 木 & & 曾 & 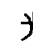 \\
\hline 井 & 俊 & 行 & 小 & 山 & 昱 & 甫 & 福 & & 宿 & \\
\hline
\end{tabular}

田宮三郎森永修高田元敬

同病理佐藤博道伊藤慈秀

\title{
A CASE REPORT OF SIGMOID DIVERTICULOSIS COMPLICATING COLOVESICAL FISTULA
}

Masato KONO, Kazuto NODA, Takahiro ASAKURA, Yasuhiro YAMADA, Masato TAHARA, Mitsunori KISO

Toshiyuki MATSUI, Ikuho KOYAMA, Tsunemasa FUKUMOMI, Kazuyoshi YOSHOKA and Masahisa ARAKAWA

Department of Surgery, Kawasaki Hospital, Kawasaki Medical school

Saburo TAMIYA, Osamu MORINAGA and Motoyoshi TAKADA.

Department of Urology

Hiromichi SATO, Jishu ITO

Department of Pathology

近年，結腸想室症は，診断技術の進歩により，その報告例が増加している。最近, 私 達は，S 状結腸㮩室症に合併した結腸膀腅瘦の 1 症例を経験したので，その症例報告に， 若干の文献的考察を加えて報告した。

症例は気尿および䔬尿を主訴とした46歳の男性で，膀胼鏡にて頂部左後壁に周囲粘膜 の発赤を併った小隆起が観察され漠孔開口部之思われたが、注腸造影では、 S 状結腸〜下 行結腸にかけ多数の䄸室を認めたものの, 両病変の間に瘦孔は確認できなかった.

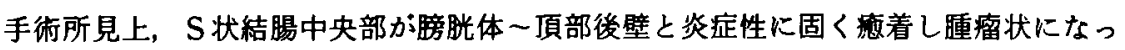
ていた，瘦管の 1 部を含めて $\mathrm{S}$ 状結腸を切除し, 端々吻合した後, 膀胜を瘦管部を含め て部分切除し，2 層に释合閉鎖した。術後 8 日目に結腸吻合部の䊕合不全をきたし，人 工肛門を造設した。翌年 5 月に人工肛門閉鎖を行った。

結腸䄸室症の多くは，外科的治療の対象とはならないしかし，䅣室炎による合併症 を生じた場合は，外科的治療が必要となる．本疾患による合併症の1つである結腸膀羘 㾇は，欧米では多数の報告例があるが，本邦では，私達が集計した限りでは，自験例を 含めて24例のみであった，その男女比は，17：7 と男性に多く，40６0歳代に多く見ら 九た。症状は, 膀腅郕激症状, 気尿, 䔬尿なと, 泌尿器科的症状が多かった。手術方法 については，最近では，One-stage operation で好成績を納めたといら報告が多いか，本 症例のような, 炎症性変化の強い症例ではMultiple-stage operation る考慮されるべき であろら。 


\section{績 $\quad \mathbf{Z}$}

近年, 結腸秝室症は, 診断技術の進歩, 食生活の欧 米化，高龄化社会等にともない，その報告例が增加し ている，最近，私達は結腸膀胱漠を合併した S 状結腸 悡室症を释検したので，その症例報告をおこならと共 に，本邦23報告例について文献的考察を加えたので報 告する.

\section{症例}

症例：46歳, 男性, 会社員.

主訴：下腹部異和感, 発熱, 気尿, 䔬尿。

既往歴：26歳の時, 左腎結石で腎摘出，糖尿病（現 在, 食慨療法中）

現病歴：昭和55年 1 月，殿部を強打し，以後下腹部 異和感があった。 2 月頃から, 時々, 発熱, 気尿, 䔬 尿があったが放置していた，5月15日，上記症状が持 続するため某病院に入院し，精査を受けるす原因不明 で，7月25日退院，8月 5 日当院泌尿器科に，精査の 目的で入院した，

現症：身長 $169 \mathrm{~cm}$, 体重 $70 \mathrm{~kg}$, 栄養良. 賓血, 黄疸 は認めず, 胸部に異常所見はなかった。腹部は平担で, 畽瘤を触知しなかったが，左下腫部に軽度の王痛が あった．血王134-90 $\mathrm{mmHg}$ ，脈拍 90 回/分.

一般検查成樍：表 1 の通り。

膀胱鏡所見：容量約 $300 \mathrm{ml}$, 粘膜全体に充血が見ら れたが，両側尿管口の形態は正常. 䁤脱頂部左側に中 心が楩凹した粘膜の浮腫状隆起を認め掼孔開口部と思 われたが，カテーテルは㧴入できなかった。

レ線所見：骨盤単純撮影で膀胱内ガス像は不明で あった。排泄性堅孟造影では，右腎孟はやや抁張し，

\section{表 1 検㚗所見}

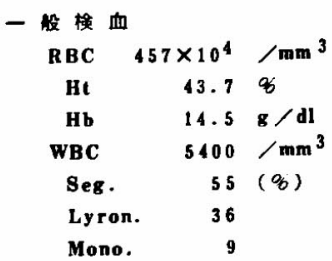

旰機能换査
S. P. $\quad 7.7 \mathrm{~g} / \mathrm{dl}$
Alb $4.3 \mathrm{~g} / \mathrm{dl}$
GIb $3.4 \mathrm{~g} / \mathrm{dl}$
GOT $191 \mathrm{U} / \mathrm{d}$
GPT 13 I U $/$ dI
ChE 353 I U / d
AIP $611 \mathrm{U} / \mathrm{dI}$
Cho. $177 \mathrm{mg} / \mathrm{dl}$

堅杯の鈍円化があり，左腎は摘出のため造影されな かった.

膀胱造影：膀胼は変形や王排像がなく，結腸内への 造影剤の移行も認められなかった（写真 1).

注腸造影：S 状結腸中央部に多数の悡室を認め, 部

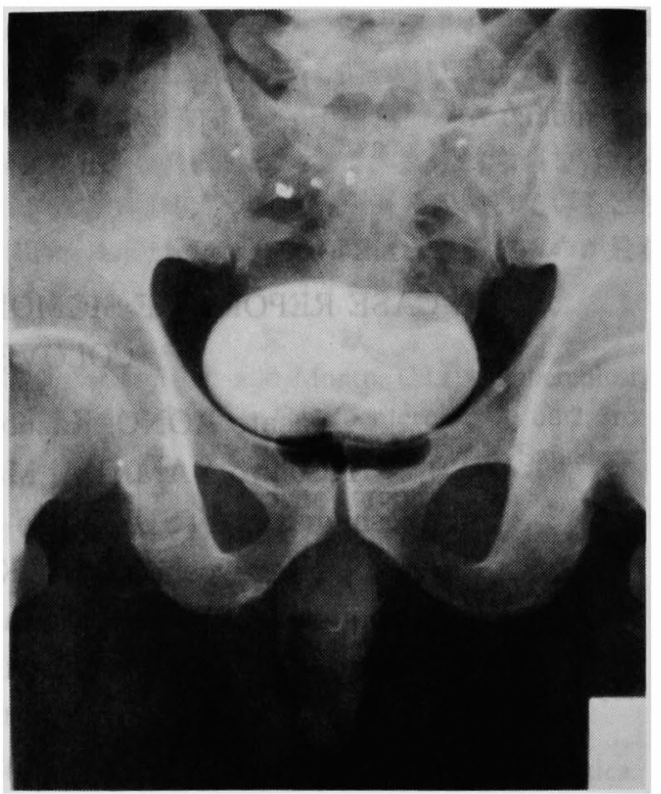

写真 1 膀胼造影

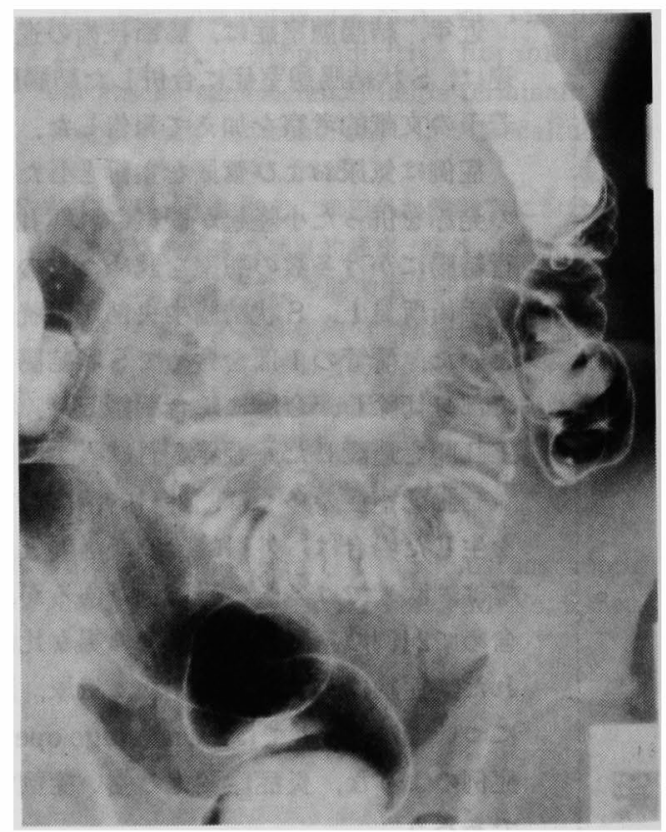

写真 2 注腈造影 
分的に鋸齿状狭窄像を呈したが, 瘦孔管は造影されず， また膀胼内への造影剂の移行も確認できなかった（写 ( 2).

以上の所見から，瘦孔確認はできなかったが，臨床 症状, 現病歴により， S 状結腸䅣室による結腸膀胼瘦 と診断し、昭和55年 8 月 18 日, 全麻下に手術を施行し た.

手術法および所見：膀脂頂部後壁と S 状結腸中央部 前壁は強く炎症性に病着し，同部結腸壁は 10 数 $\mathrm{cm}$ に わたり肥厚が強くみられた，瘦管を含めて結腸を可及 的に正常な部位まで切離し，端々吻合を行った，膀胼 は, 瘦管部を含めて部分切除し，切離端は 2 層に縫合 閉鎖した。

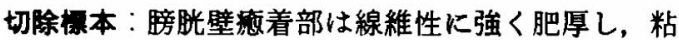
瞙面まで波及した明らかな膿瘍を含んでいた。切除結 渴壁は全体的に肥厚し，粘膜面には，多数の敗室がみ られた。 そのうちの 1 個に扰いてソンデの㧌入により 膀腃へ連続した瘦孔が確認された（写真了）.

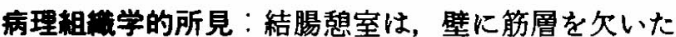
仮性㮩室であった。㮩室下の采膜下脂肪織には，巨大

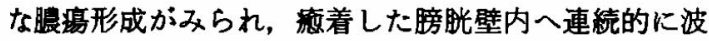
及して㿉管をなしていた（写真 4 )，膿瘍壁には，強い 線維化と炎症性細胞漫潤がみられ，また結腸側の膿場 壁内には，一部で腸粘膜が包埋されており，また膿瘍 内にはバリウムを貪食した組織球がみられたことか ら、この膿啺と上方の秝室の連続は間接的にも証明さ れた。

術後経通：術後 8 日目頃から突然に下腹部痛を訴 之，裏急後重も出現した，注腸造影にて結腸端々吻合

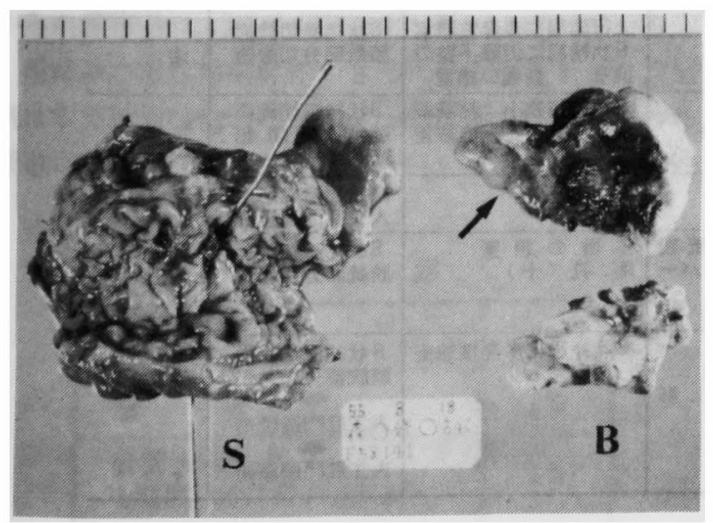

写真了摛出标本

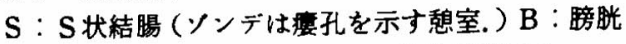

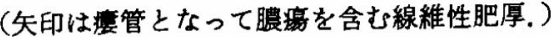

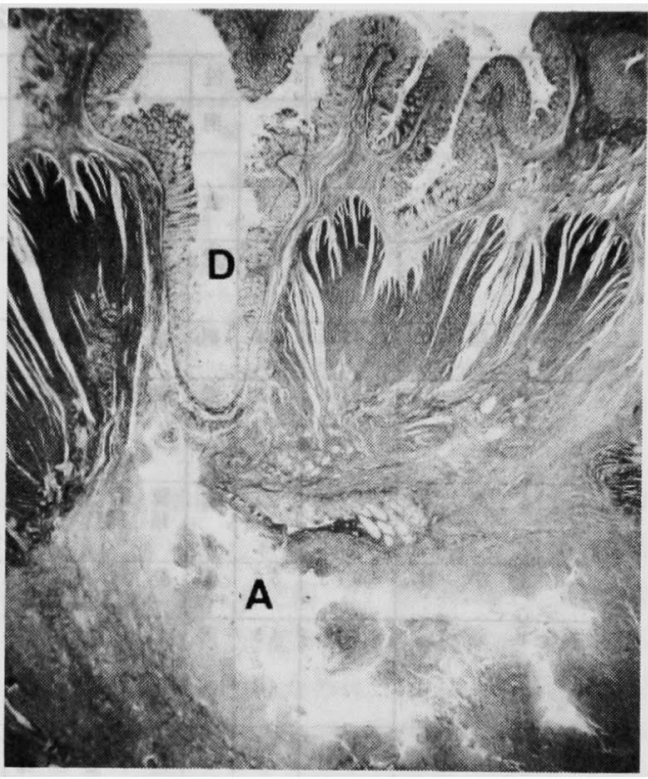

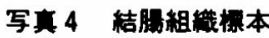

$\mathrm{D} ：$ 䅫室（この写真では漠孔が示されていない）

$\mathrm{A}$ ：膿瘍一贋管一 $(\mathrm{HE} \times 6)$

部の䋖合不全と診断し, 人工肛門造設術, 肛門断端縫 合閉鎖術およびドレナージを施行した，術後35日目に 軽快退院したか，翌年 5 月再入院させ，人工肛門閉鎖 術を行った，現在，再発の徴候はなく健在である.

\section{考㲾}

結腸䕀室症の頻度は，診断技術の進歩と，食生活の 欧米化，ならびに高齢化に伴い増加傾向にある．わが

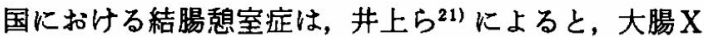
線検査症例中の $5.5 \%$ に見られ，性別男子7.7\%，女 子3.6\%と2.1：1の発生頻度であるが，年龄別頻度を 見ると，加龄とともに段階上界を示していると言う。 また部位別には，若年層では右側型が90\%以上である か，加龄にともない左側壁が増加している，結腸想室 はその大多数になんらかの症状がみられるが，特に左 側型で多く，また合併症もこの型に多い。

結腸悡室症の合併症としては悡室炎, 穿孔, 出血, 膿瘍形成, 瘦孔形成等があり，外科的治療の適応とな るものも多い，瘦孔形成のうち，S 状結腸膀胱瘦は比 較的稀な疾患であるが，欧米では，左側型が多いこと を反映して，多数の報告例があり，Mayo ら と, 結腸稳室症における全合併症のうち $22.8 \%$, Colcock $ら^{23)}$ の集計では, 結腸䅣室全手術件数の $19.0 \%$

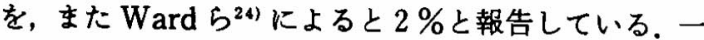
方本邦では，自験例を含め24例が報告されているにす 
衰 2 本邦啹告例

\begin{tabular}{|c|c|c|c|c|c|c|c|c|}
\hline 告者 & 年 度 & 年令 & 性 & 主 & 渐法 & 注 $\mathrm{M}$ 所 兄 & 治 法 & 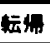 \\
\hline 1. 佐 & 1937 & 47 & 男 & 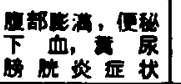 & 证口大酒造影 & & 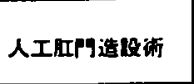 & $?$ \\
\hline 2. 肉 村 & 1957 & 32 & 女 & 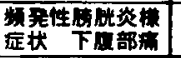 & 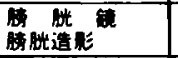 & & 手 & 治 \\
\hline 3. 見 & 1970 & 44 & 男 & 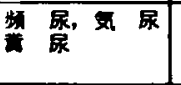 & 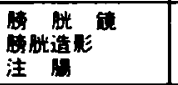 & & 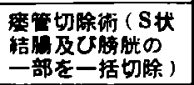 & $?$ \\
\hline 4. 郝 部 & 1971 & 66 & 男 & 気 尿. 锺 尿 & 注 & 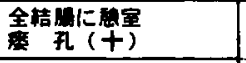 & 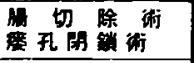 & 治 \\
\hline 5. 谷 $川$ & 1972 & 56 & 男 & 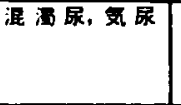 & 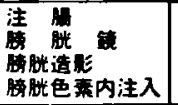 & 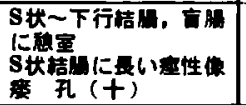 & 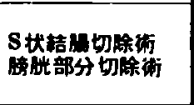 & 治 \\
\hline 6. 武 本 & 1973 & 75 & 女 & 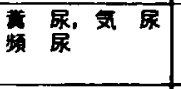 & 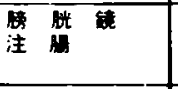 & 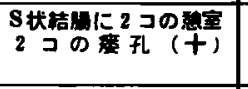 & 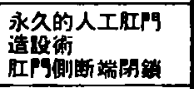 & 治 \\
\hline 7. 小林 & 1973 & 56 & 男 & 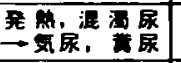 & 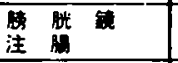 & & 屡孔開销術 & 治 \\
\hline 8. 第 湿 & 1973 & $\begin{array}{l}45 \\
42\end{array}$ & 男 & 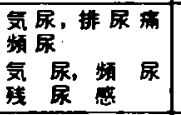 & 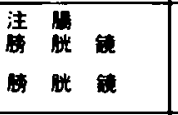 & 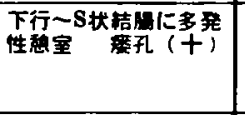 & 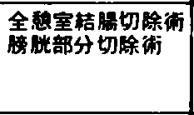 & $\begin{array}{l}? \\
?\end{array}$ \\
\hline 9. 岡 部 & 1974 & $\begin{array}{l}45 \\
68\end{array}$ & $\begin{array}{l}\text { 男 } \\
\text { 男 }\end{array}$ & 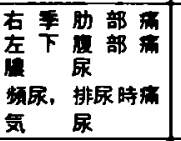 & $\begin{array}{l}\text { 注 } \\
\text { 㩆 } \\
\text { 注 }\end{array}$ & 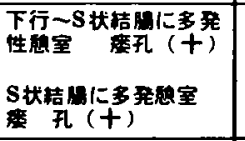 & 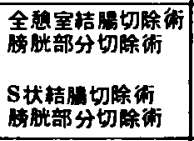 & $\begin{array}{l}\text { 治 } \\
?\end{array}$ \\
\hline 10. 吉 网 & 1974 & $\begin{array}{l}56 \\
58 \\
\end{array}$ & $\begin{array}{l}\text { 男 } \\
\text { 男 }\end{array}$ & 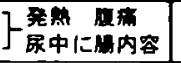 & 被 & 1 列に雨 $f(+)$ & $?$ & $?$ \\
\hline 11. 重 田 & 1974 & 66 & 女 & 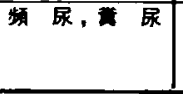 & 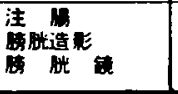 & $\begin{array}{ll} & \text { 垔(t) } \\
\text { 扎 }\end{array}$ & 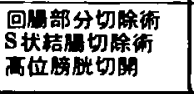 & 治 \\
\hline 12. 田 & 1976 & 76 & 男 & 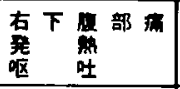 & 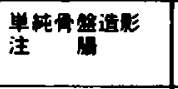 & 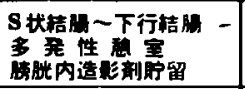 & $?$ & $?$ \\
\hline 13. 閐 空 & 1977 & 40 & 男 & 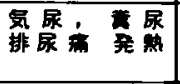 & 注的 & 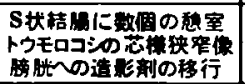 & 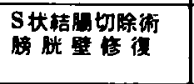 & 治 \\
\hline 14. 等屡 & 1978 & 62 & 女 & 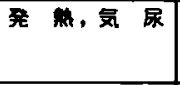 & 注 & 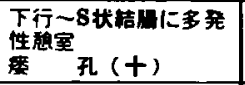 & 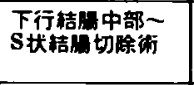 & 治 \\
\hline 15. 石塚 & 1979 & 62 & 女 & 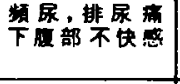 & 注的 & 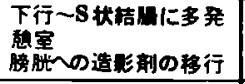 & 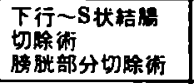 & 治 \\
\hline 16. 3 & 1980 & 41 & 男 & 酸炎 & & & 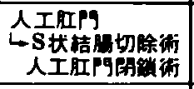 & 治 \\
\hline 17. 五十 & 1980 & 41 & 男 & 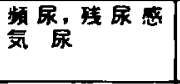 & 注 & 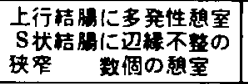 & 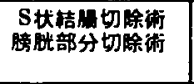 & 治 \\
\hline 18. 石挥 & 1980 & 53 & 男 & 気尿，䢽尿 & 注 & 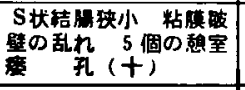 & 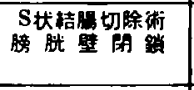 & 治 \\
\hline 19. 池 永 & 1980 & 69 & 女 & $?$ & $?$ & $?$ & 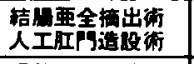 & $?$ \\
\hline 20. 石本 & 1981 & 77 & 男 & $\begin{array}{l}\text { 気底, 物尿 } \\
\text { 霜 }\end{array}$ & 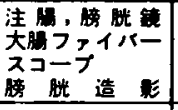 & 要数の & 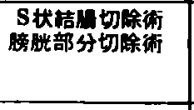 & 治 \\
\hline 21. 自略的 & 1982 & 49 & 男 & 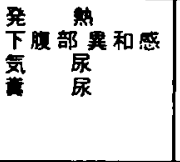 & 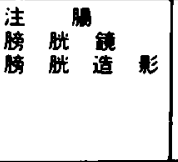 & 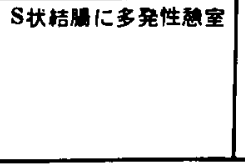 & 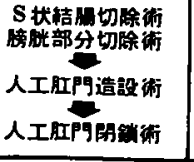 & 治 \\
\hline
\end{tabular}


ぎない(表 2$)^{11-20)}$.

これら本邦報告例を検討すると，性別では17：7と 男性に多く，これは欧米でも同様な傾向が見られてい る、女性に少い理由としては，結腸熄室症の䍜患率自 体が低いこと,子宮およびその付属器が介在するため, 結渴憩室一膀胼間に㿉孔が形成されにくいものと思わ

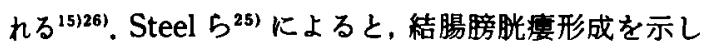
た 7 例の結腸憩室症女性例すべてが，高龄のための子 宮萎樎か子宮摘出術を受けていたと報告している。痽 患年龄は本邦では，40～60歳代に多く，全体の83\%と しめていた，病悩期間は比較的長く，本邦例では， 1 カ月～15年と大きい差が見られたが，欧米でも同様の 㑯向が認められている27.

症状については，本邦および欧米例ともに膀胱刺激 症状を初発症状とするすのが最も多く，記載のある 22 例中19例 (86\%) に認められ，次いで気尿14例 (64\%), 䔬尿10例 (44\%)，発熱 6 例 (27\%) および下腹部痛 5 例 (23\%) と泌尿器科的症状が多かった（表 3 ）。頻尿， 朖尿，排尿時痛等の膀胀刺激症状が出現することは結 腸憩室の穿孔あるいは穿通によって，すでに膀羘周囲 炎を併発していることを意味しており，さらに膿掦形 成を堹て，耪脱壁へ接続する瘦管が形成され，ついに 気尿，瘦尿等の症状が出現するむのと推定されている が28)，かかる摸管形成過程は私達の例でも充分推测出 来るすとと思われた。

消化器症状は腹痛括よび便潜血陽性以外は，本邦例 では、ほとんど見られなかった. Shatila ら29)は，結腸 膀脱瘦 2 例で肛門からの尿排泄を報告しており，本邦 でも，武本ら゙にによるは同様な報告があるが, Colcock ら ${ }^{23)}$ によると，外尿道の閉鎖がある以外は，肛門 からの尿排泄は、はとんど発生しないと述べている。

尿路系の重症感染症や，さらには敗血症をきたした 例は本邦報告24例ではなく，一般に前立腺疾患等の外 尿道口閉鎖や消化管閉塞症を合併している場合に例外

表了主 訴

\begin{tabular}{|c|c|}
\hline 気 & 14 \\
\hline 㟟 & 10 \\
\hline $\begin{array}{l}\text { 脇脂炎栏症状 } \\
(\text { 頻尿，混濁尿，排尿痛） }\end{array}$ & 19 \\
\hline 発 & 6 \\
\hline 下腹部 痛 & 5 \\
\hline
\end{tabular}

表 4 搂孔礁愢

\begin{tabular}{|c|c|}
\hline 栋 & 田思例／虑行例 \\
\hline 注渴 & $14 \% 19(74 \%)$ \\
\hline 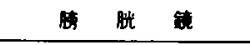 & $6 / 15(108)$ \\
\hline 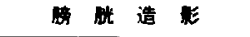 & $3 / 9(33 \%)$ \\
\hline 大的ファイパースコーフ & $0 / 3(0 \%)$ \\
\hline 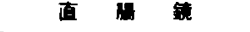 & $0 / 2(096)$ \\
\hline
\end{tabular}

的に発生するようである293301.

結腸膀胼瘦の診断には，諸検查の中で注腸造影法お よひ膀胱鏡検查が最も有用とされている，注腸造影法 により，1）大腸病変の把握，2）瘦孔の確認，3）耪胱 内への造影剂の移行, を証明することが可能であるが, 2）3）の所見がみられたのは， $16 \% ７ 8 \%$ と報告者 によりかなりの差が見られる25227)29330). 検討した本邦 報告例では，記載のある19例中14例例 $(74 \%$ ）に瘦孔 確認および膀胱内への造影剂の移行が見られた（表 4). 耪胱鏡は, 肉眼的に瘦孔確認が可能な点之膀脱内 粘膜の肉眼所見（必要なら生検）が得られることで有 用であるが，瘦孔の確認は一般に困難で，欧米文献で は，33\% -57\%の症例でなされているにすぎな (25)27313132).しかし，ほとんどの例で、睆胜頂部左側壁 に限局性の発赤浮腫等の炎症所見が見られ，瘦孔の存 在を疑わせる所見が得られている。本邦24報告例につ いては，膀胱鏡検査が行われた15例中 6 例 $(40 \%)$ に 上記の瘦孔が確認されており，またこの全例に上記の 異常所見が見られている。 また結腸への㾇孔の確認の ために, Methylen blue の膀胱内注入も試みられてい $3^{29 / 330)}$.

な扮膀胼造影による診断率は低いとされているが， steel ら ${ }^{25)}$ は28\%に瘦孔を確認し, 本邦では, 武本ら が経時的透視下耪胱造影の有用性を報告している。本 法による結腸膀脱瘦の確認は，本邦報告例では 9 例中 3 例 (33\%) で可能であった。

排泄性腎盂造影は，膀脱相で掼孔を確認できる可能 性があるが、診断率は極めて低いと言われている27.し かし、稀ではあるが，水堅症を合併した結腸膀胼瘦も 報告されており ${ }^{34)}$ ，腎機能や上部尿路系の精査のため には必要な検査である。

直腸鏡あるいは大腸フォイバースコープは，大晹病 変が直視できるので有用な検查法といえるが，これら による膺孔の確認は困難なようで，また炎症を伴ら場 合には疼痛のため鏡の拽入自体が困難なことも報告さ 
れている20).

以上の䠛床症状及び諸検查所見から，結腸䄸室炎に よる結腸膀䁋瘦の確診率はかなり高いるのと思われ る.

治療法について，結晹息室症は外科的治療を要しな い場合が多い，しかし，合併症が出現すれば外科的治 療が当然必要となる。特に結腸膀胼㿉は, 保存的治療 によっては嫫孔の閉鎖は期待できない26)。結腸膀脱瘦 は，そのはとんどが桑急手術の対象となることは少な く25)一般に充分な保存的治療之術前管理を行った待 期手術によってなされている，術式については，古く は人工肛門造設術多用されていたが22)，人工肛門造 設だけでは、款室による瘦孔は閉鎖されず26)，また瘦管 切除のみでも不充分であり，瘦管を含むS 状結腸切除 と耪胼の部分切除が必要であろう.

以上のよ5に, 術式にはOne-stage operation と Multiple-stage opration が考えられているが，その選 択については, Ward ら ${ }^{24)}$ は Multiple-stage operationがより安全であると述べている。しかし最近で は，多くの報告者かi One-stage operationの有用性を 述へてており 25/26/28)35), その根拠として, 抗生剤の発達, 術前術後管理の進歩および入院期間の短摍をあげてい ろ. One-stage operation に関して重要なことは, 1）健 常な腸管で吻合すること,2）伆合部に過鄱な祭張がか からないこと，3）充分な術前処置，4）㽬室結腸の切 除，を考虑することにあると思われる，全結晹息室例 や左側結腸多発例では，すべての悡室結腸を切除する 必要はないとされるが，S 状結腸㮩室の場合は，でき る限り全病策を含む広い範囲の切除が望むしい。 Hardy ら ${ }^{36)} は$ One-stage operationを行った S 状結 腸䕀室炎による結腸膀脱瘦の再発例を報告している。 Multiple-stage operation の適応として, Ray $5^{27) は, ~}$ 1）急性経過をとるもの，2）膿煌合併例および3）蜂窝 織炎合併例をあげており，さらに Hardy ら ${ }^{36)}$ は，肥满 を加えている，资症性所見の強い場合，および腸閉塞 を伴うむの，全身状態の悪い場合は，Multiple-stage operationが安全なよ5である. 記載のある本邦報告 17例を見ると, One-stage operation が13例に, Multiple-stage operation が自検例を含む 2 例に，瘦管切 除, 結腸切除拉よび永久人工肛門造設が 2 例，瘦孔閉 鎖のみ, 人工肛門造設のみが各 1 例となっており Onestage operation が多く，好成樍を得ている。自呀例で は, 結腸端々吻合部の䋖合不全のため Multiple-stage operationを余儀無くされたが完治できた. One-stage operation, Multiple-stage operationいずれを選択す るかは，個々の症例での慎重な考虑が必要と思われる.

\section{桔磦}

$\mathrm{S}$ 状結腸秝室症に合併した結腸膀胱瘦の 1 治釦例を 報告し，本邦報告23例とともに若干の文献的考察を加 えた. 本疾患は，左側型秝室症の増加にとるない，今 後その報告が増加するものと思われる.

（本論文の要旨は，第44回日本䠛床外科医学会総会(東京) において発表した。）

\section{文献}

1）佐藤皇一：繁室性 S 字状結腸资, Sigmoiditis divertricularis 臨床医学, $25: 586-587,1937$.

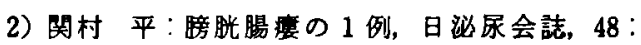
72-73, 1957.

3）勝見哲郎, 板谷興治：耪胱 S 状結腸瘦の 1 例, 日泌 尿会誌，61：618，1970.

4）服部孝至，林喜代治，品川去：SMONを併発し た結渴想室症の䁤腅内穿孔の 1 例, 日消会誌, 68 ： $576-577,1971$.

5）谷川允彦，柏原卓夫，倉本信二：S 状結渴膀胱晨を 合併した大腸惒室症の 1 例, 日本大腸肛門誌, 25 ： 34-35, 1972.

6）武本征人，坂口 强，宮川光生：S 状結渴稳室症か：

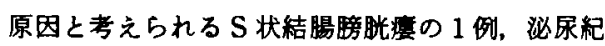
要, $19: 975-981,1973$.

7) 小林 収, 三失英輔：Vesico-sigmoidal fistula の 1 例, 日泌尿会誌，64：679，1973.

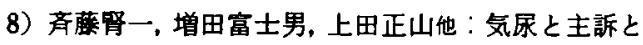
した膀腃 S 状結渴度の 2 症例, 日泌尿会誌，64： 601-602, 1973.

9）岡部紀正，石川正昭，阿部伸夫他：胆石症を伴った

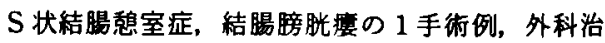
㫫, $31: 215-220,1974$.

10）吉岡照樹, 服部竜夫, 三浦 䜵他：想室穿孔に上る と思われる S 状結腸膀胱瘦の 2 治検例, 日消外会 誌, $7: 503-504,1974$.

11）黒田吉隆, 白石 制, 正司政夫他：S 状結腸膀睄瘦 の 1 例，臨外，29:955-959，1974.

12）多田信平：大腸想室炎，S 状結腸膀胱浱, 臨放, $21: 1179-1180,1976$.

13）岡空達夫, 鉿木栄太郎, 豊坂昭弘他：左側結腸䄸室

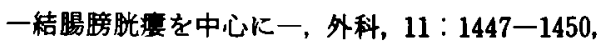
1977.

14）多羅尾信, 安藤充晴, 富田良照他: 結腸膀脱捙を合 併した S 状結腸秝室症の 1 治䋡例，胃と腸，13： 849-853, 1978. 


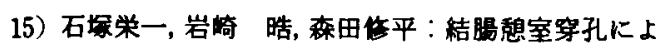
万腾胧結渴庭の 1 例一本邦14例の統計的観察一, 西日必尿，40：925-928，19778.。

16）咅多量志 1 細野 進, 三田孝行他：結腸膀脱度を 合併した S 状結渴秝室症の 1 治験例，日外会誌， $81: 95,1980$.

17）五十鼠辰男，村上信乃，藤田道夫：結湟敗室炎に上 万S 状結腸膀胱㵓の 1 例, 臨泌, 34：69-72, 1980.

18）石塚次郎，馬来忠道，青柳和彦他：S 状結腸憩室 炎に起因する S 状結腸膀胼度の 1 例, 日消外会誌, $13: 333-337,1980$.

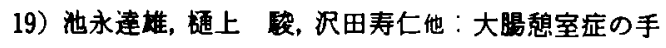
術䔔応，冒亡腸，15：825-832，1980。

20）石本音和男，家田勝幸，松本孝一他：S 状結腸室炎 が䁤胱一波及した 2 例, 大腸肛門誌，34： 537-542, 1981.

21）井上幹夫, 吉田一郎, 久保明良他：かが国なおける

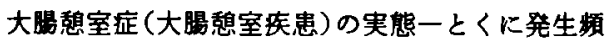
度と臨床像について一，胃と䁑，15：807ー815, 1980.

22) Mayo, C.W. an Blunt, C.P. Vesicosigmoidal fistulas complicating diverticulitis. Surg. Gynec, Obstet., 91 : 612-616, 1950.

23) Colcook, B.P. and Stahman, F.D.: Fistulas complicating diverticular disease of the sig. moid colon. Ann. Surg., 175 : 838-846, 1972.

24) Ward, J.N., Lavengood, R.W., Nay,H.R., et al. : Diagnosis and treatment of colovesical fistulas. Surg. Gynec. Obstet., 130 : 1082-1090, 1970.

25) Steel, M., Deveney, C. and Burchell, M. : Diagnosis and management of colovesical fistulas. Dis. Colon Rectum., 22 : 27-30, 1979.

26) Capenter, W.S., Allaben, R.D. and Kambouris,
A.A.: One-stage resection for colovesical fistulas. J. Urol., 108 : 265-267, 1972.

27) Ray, J.E., Hughes, J.P. and Gathright, J.B. : Surgical treatment of colovesical fistula, the value of a one-stage procedure. South. Med. J., $69: 40-44,1976$.

28）進藤和彦, 斉藤 泰, 徳永 媇他: $\mathrm{S}$ 状結腸秝室炎 による耪胼周囲炎の 1 例, 臨泌, $30: 517-521$, 1976.

29) Shatila, A.H. and Acherman, N.B.: Diagnosis and management of colovesical fistulas. Surg. Gynec. Obstet., $143:$ 71-74, 1976.

30) Heiskell, C.A., Ujiki, G.T. and Beal, J.M. : A study of experimental colovesical fistula Am. J. Surg., 129 : 316-318, 1975.

31) King, R.M., Beart, R.W. and Mcilrath, D.C. : Colovesical and rectvesical fistulas. Arch. Surg., $117: 680-683,1982$.

32) Slade, N. and Gaches, C.: Vesico-intestinal fistulas., Br. J. Surg., 59 : 593-597, 1972.

33) Kovalick, P.J., Veidenheimer, M.C., Corman, M. L., et al. : Colovesical fistula. Dis. Colon Rectum., 19 : 425-427, 1976.

34) Ng, K.K., Tan, K.M. and Lim, K.T.: Right hydronephrosis and vesicocolic fistula complicating sigmoidoclic divertriculitis. Dis. Colon Rectum., 18: 623-625, 1975.

35) McConnell, D.B., Sasaki, T.M. and Vetto, R.M. : Experience with colovesical fistula. Am. J. Surg., $140: 80-84,1980$.

36) Hardy, K.J. and Hughes, E.S.R.: Vesico-sigmoid fistula. Med. J. Aust., $60: 1141-1143,1973$. 